\title{
先天性凝固異常と妊娠分娩
}

\author{
小林 隆夫* 尾池 純子* 寺尾 俊彦* 神谷 忠** \\ 鯉江 捷夫** 真鍋 修身*** 今井 信昭****
}

\section{Discussion of 6 cases (10 pregnancies) of the congenital coagulation disorders during pregnancy and labor}

\author{
Takao KOBAYASHI*, Junko OIKE*, Toshihiko TERAO*, \\ Tadashi KAMIYA**, Katsuo KOIE**, \\ Osami MANABE*** and Nobuaki IMAI****
}

Key words : coagulation factors deficiency, hemostasis during labor, replacement therapy, vaginal delivery, heredity

The cases of pregnant patients with the congenital coagulation factors deficiency, or its reduction, who underwent successful deliveries are very uncommon, so the management of hemorrhage during pregnancy and labor has not been established. As we experienced 6 cases (10 pregnancies) of the congenital coagulation disorders, we analysed the change of coagulation factors during pregnancy and clarified the change of hemostatic mechanism during pregnancy and the management of labor.

The activity of factor VIII in plasma increased during pregnancy, namely 108 $\pm 10.2 \%$ in non-pregnant women, $150 \pm 53 \%$ in pregnant women at $3 \mathrm{rd}$ month, $173 \pm 47 \%$ at 5 th month, $250 \pm 76 \%$ at 8 th month. Also in plasma of factor VIII deficiency patients, such as von Willebrand's disease, mild case of hemophilia A carrier, its activity increased during pregnancy and exceeded $100 \%$ at 10th month, so they underwent successful deliveries without any replacement therapy. But in one case of severe hemophilia A carrier, factor VIII activity in plasma didn't increase over $20 \%$ of normal, so she, who underwent Cesarean section because of CPD, was treated with AHF replacement therapy. In this case hemorrhage from uterine cavity was normal, but hemorrhage from the operative wound couldn't be ceased easily.

* 浜松医科大学産婦人科 [广 $431-31$ 浜松市半田町3600], Department of Obstetrics and Gynecology, Hamamatsu University School of Medicine, Hamamatsu, Japan.

** 名古屋大学医学部第一内科, First Department of Internal Medicine, Nagoya University School of Medicne, Nagoya, Japan.

*** 大垣市民病院産婦人科, Department of Obstetrics and Gynecology, Oogaki City Hospital, Oogaki, Japan.

**** 半田市民病院産婦人科, Department of Obstetrics and Gynecology, Handa City Hospital, Handa, Japan. 
We concluded as follows :

1. Even in patients of the congenital coagulation factors deficiency decreased activity of coagulation factors increases during pregnancy.

2. Even in these patients hemorrhage from uterine cavity can be ceased by the biological ligation of uterine muscle and by the extrinsic coagulation mechanism of tissue thromboplastin in placenta and decidua.

3. Hemorrhage from the wound of laceration or incision can't be ceased without replacement therapy.

4. Therofore careful, intentional and vaginal delivery is the absolute principle. Cesarean section should be elected for obstetric reasons only.

5. The heredity to newborn infant should be considered.

\section{緒言}

先天性血液凝固異常を持つ患者は稀であり, 重症では早逝することが多いので，乙れを持つ 患者が妊娠することは一層稀であるままた先天 性血液凝固異常患者の大部分を占めている血友 病 $\mathrm{A}$, 血友病 $\mathrm{B}$ は伴性劣性遺伝であり, 通常女 性にはみられないので, 先天性血液凝固異常患 者の妊娠分婏例はきわめて稀な乙とである.し かし最近の血液凝固学の進歩によって患者の生 存年数む延長し，てれらの患者が妊娠分娩する 機会も多くなってきた．とてろがてれらの患者 の妊娠分婏は大きな問題を抱えており，とくに 妊娠継続可否の決定や妊娠中および分娩時の出 血対策に関して未知な点が多い。そこでわれわ れが取扱った先天性血液凝固因子低下症患者の 妊娠分婏経過を報告するととあに，凝固因子の 低下が妊娠の進行ととあににいかなる変化を示 したかを正常妊婦と比較検討し，乙れらの患者 の妊娠分婏の管理方法を明確にせんとした。

\section{I. 方 法}

われわれは今までに先天性凝固因子低下症と して von Willebrand 氏病 1 例（2 妊娠， 2 分 婏), 血友病 $\mathrm{A}$ 保因者 2 例（重症型 1 例（2 妊 娠, 1 分婏), 軽症型 1 例 (2 妊娠, 2 分娩)), 第 V 因子欠乏症保因者 1 例 (2 妊娠, 2 分婏), および先天性無線維素原血症保因者 1 例（1 妊 娠， 1 分娩）を経験し，その他血小板機能異常 に基づく凝固異常として Bernard-Soulier 症候 群を経験したので，乙れらの患者の妊娠の進行
に伴う凝固因子の変動, 分婏時の管理法につい て検討した。

\section{II. 結 果}

von Willebrand 氏病患者は 2 回妊娠したが, 2 回と屯正常分婏にて無事生児を得ることがで きた．妊娠初期，中期には第VIII因子活性 が 低 く, 出血傾向 (鼻出血, 血尿) が認められた が，妊娠の進行ととあに第 VIII 因子活性は上昇 し，妊娠10か月では $100 \%$ に達し，第V四因子製 剂 (AHG) を輸注することなく分婏させ得た。 また分婏時出血量は第 1 回目 $165 \mathrm{~m} l$, 第 2 回目 $350 \mathrm{~m} l$ と正常範囲内であった。一般に第V四因子 活性值は正常非妊婦では $108 \pm 10.2 \%$ あるが， 正常妊娠 3 か月で150土53\%，妊娠 5 か月で173 $\pm 47 \%$, 妊娠 8 か月で $250 \pm 76 \%$ 之妊娠の進行 ととあに増加し（図 1)，陣痛の発来之之むに 著増, 産䙏で減少して正常值に復するてとがわ かった。 そてで妊娠前に第VIII因子活性が50\%程 度であった血友病 $\mathrm{A}$ 保因者について測定した之 ころ，健康人と同様に妊娠によって第VIII因子活 性は增加し，妊娠末期には活性值 100\% を超え た（図 2).われわれの経験した症例のうち軽 症血友病 $\mathrm{A}$ 保因者は 2 回妊娠し 2 回分娩した が，いずれあ分婏時出血量は正常範囲内で，第 VIII因子製剂を輸注することなく分婏させ得た。 しかしもう 1 例の重症型血友病 $\mathrm{A}$ 保因者では第 VU⿴囗大因子活性が著明に低下した. 第 1 回目の妊娠 は不全流産をし, 子宮内容清掃術を行ったが, 子宮腔からの出血はほぼ正常であるあ, 子宮胵 部にかけた Museux 針子の小さな傷跡からの出 


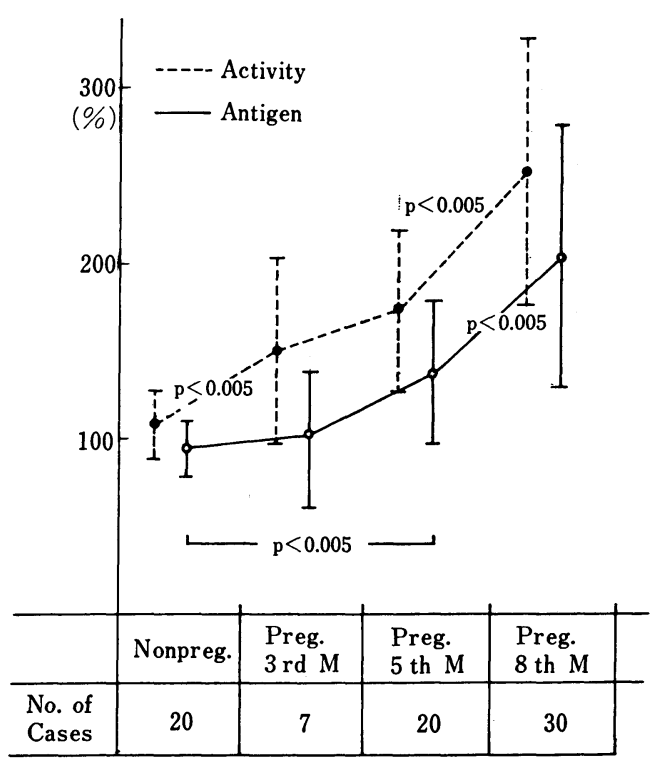

Fig. 1 Changes in the AHF activity and AHF-related antigen in normal nonpregnant women and in normal pregnant women (Mean $\pm \mathrm{SD}$ )

血が止血せず，翌朝ショックとなった．このと とについての考察は後述する.ちなみに第VII因 子活性は約 $20 \%$ であった。続く第 2 回目の妊娠 あ第VII因子活性は低く，妊娠末期でも20\%以下 であったので，経時的に第V四因子製剤を輸注し ながら産科的理由（児頭骨盤不均衡）で帝王切 開術を行い，無事生児を得ることができた。し かし産褯10日目頃より十二指腸潰瘍となり，乙 こよりの出血を止めることができず，産裖 1 か 月目に死亡した．真性第 V 因子欠乏症の分婏例 は報告されていないが，われわれが取扱ったの は活性值 $50 \%$ の 第 V 因子久乏症保因者の 2 妊 娠, 2 分婏である. 2 回とむ第VII因子同様妊娠 の進行之とあに活性值が増加し, 分婏時には 100 \%以上にむなり，無事分婏させ得た．真性先天 性無線維素原血症患者の分婏例はまだないと思 われるが，われわれは本症の保因者と思われる 妊婦の分婏を取扱った。乙の患者は 3 回経産婦 であるが，第 2 児と第 3 児を臍出血のため死亡 させているため本症を疑い, 妊婦血中フィブリ ノーゲン量を測定したところ妊娠 9 か月で 360 $\mathrm{mg} / \mathrm{d} l$ であった. 分婏は正常分婏であったが, 臍帯血のフィブリノーゲンは $0 \mathrm{mg}$ で免疫学的

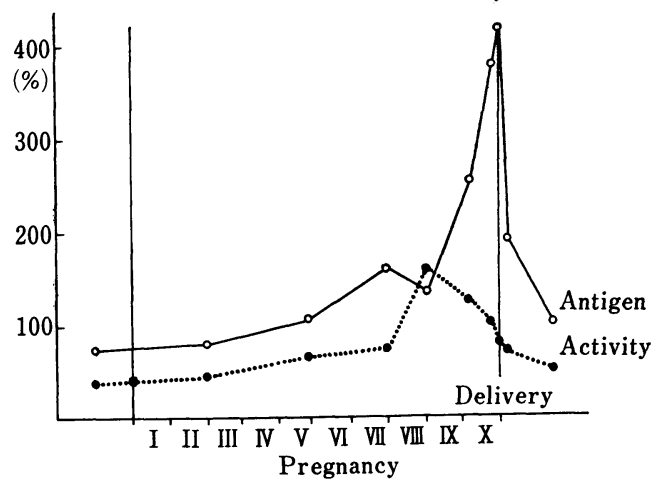

Fig. 2 Changes in the AHF activity and AHF-related antigen in a case of hemophilia A carrier

にあ全く証明されず，臍帯血はトロンビンを加 えても全く凝固しなかった，すなわち新生児は 先天性無線維素原血症であり, フィブリノーゲ ンを 3 回注射して血液は正常に凝固するように なり, 臍帯む 8 日目に脱落, 無事退院した。さ らに Bernard-Soulier 症候群患者の 1 妊娠, 1 分娩を取扱った. 本症は血小板数の減少と形態 学的に異常な巨大血小板の出現を特徴とする出 血性素因で, 常染色体性不完全劣性遺伝といわ れる. 患者は 1 回経妊 1 回経産婦で, 前回は分 婏時出血量が $750 \mathrm{~m} l$ であったが輸血の必要はな かったという．今回は妊娠10か月に下肢に紫斑 が生じ, 血小板数 1 万 $/ \mathrm{m} \mathrm{m}^{3}$, 出血時間 15 分以 上のため当科紹介され, 本症と診断, 計画的分 娩誘発のため入院となった. 分婏時は分婏第 1 期から出血が持続したため血小板輸血を施行, 分婏後屯新鮮血輸血を施行し, 無事生児を得 た。なお，分婏時出血量は $880 \mathrm{~m} l$ であった。

\section{III. 考 案}

先天性血液凝固異常患者における妊娠 - 分婏 の管理方法は国内外の成書 ${ }^{122)}$ をてむ明確に 記載されておらず，ただ凝固因子低下に際して 補充療法をすすめているにすぎない。われわれ が以前に報告 ${ }^{3}$ したときはまだ症例む少なく， 管理規準としては明確にしなかった。しかし今 回は症例も増え, てれらの患者の妊娠中および 分婏時の管理方法に一定の規準を設け, さらに 分婏時子宮出血の止血機序を解明しえた. 総括 の項にまとめて述べるが，今までこれらの患者 
Table 1 Five important haemostatic mechanism in labor
1. Increase of the activity of blood coagulation factors in plasma during pregnancy
2. Biological ligation of uterine muscle
3. Extrinsic coagulation mechanism of tissue thromboplastin in placenta and decidua
4. Increase of anti-fibrinolytic substance such as urokinase inhibitor in placenta
5. Increase of blood coagulation factor XIII in placenta

の妊娠・分婏には未知な点が多く, 危険と思わ れていたものが今後はより安全なうちに生児を 得ることが可能となろう.

さて，一般に正常妊婦では妊娠の進行とと屯 に多くの凝固因子は増加（第XII因子之第 XI因子 は例外）し，とくに第VII因子，第 X因子は妊娠 末期には活性值250\%にあ増加する（図 1). 妊 娠に合併する先天性血液凝固異常の中では最む 多い第VII因子低下症においても妊娠の進行と之 あに増加を示し（図 2)，軽症血友病 A 保因者 や von Willebrand 氏病では妊娠末期には活性 值 100\% 超えるので, 妊娠の継続は可能で, 補充療法をすることなく分婏させ得る．むし妊 娠末期に第VIII因子活性が50～60\%以下なら新鮮 血輸血や AHG 輸注で活性を上昇させてから分 婏, 原則として裂傷, 切創のない経腟分婏を行 う.しかし重症血友病 A保因者では妊娠末期で あ活性值が上昇しないことがある。乙の場合は AHG を輸注しながら慎重に経腟分婏を行う. われわれの経験した 1 例の第 1 回目の妊娠は不 全流産であり，子宮内容清掃術を施行したが， 子宮腔からの出血は正常であるも，子宮腔部に かけた Museux 鉗子の傷跡からの出血が止まら なかった．乙のことは子宮腔からの出血が子宮 筋の収縮（生物学的結禁）によって止血したて と，またたとえ第V四因子が低下していても子宮 内膜面（脱落膜）に存在する組織トロンボプラ スチンによる外因系血液凝固機序がこれを補い 止血したことを意味する。一方 Museux 鉗子の 傷跡からの出血は，子宮胵部には子宮筋が存在 しないてと，したがって生物学的結紮がなされ ないてと，拈よび外因系血液凝固機序が十分に 働かないととを意味する。乙れと同様な理由で 腹壁や腟会陰の切創, 裂傷からの出血は止血し にくい.したがって凝固因子の低下している症
例はむちろん凝固因子が妊娠の進行とともに十 分に増加している症例でも, 血液凝固異常を伴 う患者の分婏は原則として経胵分婏を行うべき である。しかし止むをえず切創，裂傷を生じた 場合，ここからの出血は補充療法を行わない限 り止血しないであろう。表 1 亿分婏時止血機序 の特徵を示した。

われわれはいまだ真性血友病症例を扱ってな いが，むし真性血友病なら優生学的にも問題で あり，原則として中絶であろう。ただし，だう しても挙児希望なら羊水の染色体分析を行って 女児なら出産させてあよいだろう。

第 V 因子屯第V而因子同様に妊娠の進行ととも にに増加するので，第 V 因子久乏症保因者です 妊娠の継続は可で，正常分娩可能である.

真性先天性無線維素原血症患者は新生児期に 臍出血で死亡するか，小児期に出血死するとと が多いが，最近は適切な治療により成人に達し ている人もみられる．われわれは本症の女性を 2 人外来治療しているが，いずれあ不妊症であ り，妊卵の着床とフィブリノーゲンとの関係を 示唆するすのとして興味深く思っている.した がって本症患者の分婏例はまだないが，本症の 保因者の分婏をわれわれは経験した。乙の場合 妊婦本人よりむむしろ新生児への配慮が大切で あり，われわれの症例であ妊婦血中フィブリノ ーゲンは $360 \mathrm{mg} / \mathrm{d} l$ であったのに，臍帯血中フ ィブリノーゲンは $0 \mathrm{mg}$ であり，適切な治療に よって先天性無線維素原血症新生児の生命を之 りとめたむのである. このように先天性凝固異 常妊婦の分婏時には新生児の異常にあ目を向け ることが大切である。

Bernard-Soulier 症候群のような 血小板異常 に基づく出血性素因をもつ妊婦の分婏は，血小 板ないし新鮮血輸血も必要なので, 計画的に誘 
発分娩を行い，必要に応じて輸血をするのが原 則である。

\section{総括}

先天性凝固因子低下症における非妊時扝よび 妊娠中の凝固因子の変動を追跡し, 妊娠による 止血機構の変化抒よび分婏時の管理方法を明ら かにした。

1. 凝固因子低下症があっても妊娠中は各凝 固因子活性が増加し, 妊娠末期には正常とな る.

2. 子宮腔からの出血は子宮筋の生物学的結 禁および胎盤・脱落膜中の組織トロンボプラス チンの働きによりたとえ内因系凝固因子欠損症 でも止血しうる。

3. 切創・裂傷部からの出血は補充療法をし
ない限り止血しない。

4. 2,3 の理由により慎重な計画的な経胵 分婏を原則とする.

5. 遺伝的疾患であるため新生児への配慮む 大切である。

$$
\text { 文献 }
$$

1) 小林 隆, 他：現代産科婦人科学大系, 18; 158 160, 中山書店, 1973.

2) Joseph, J., Rovinsky, M. D., Alan, F. and Guttmacher, M. D.: Medical, Surgical and Gynecologic Complication of Pregnancy 2nd edition: 541 547, Williams \& Wilkins, 1971.

3）寺尾俊彦：血液疾患と娃娠分婏．産婦人科治 療, 32; 305 317, 1976.

\section{○わが国唯一の葉酸補醅素研究の完全な集大成!}
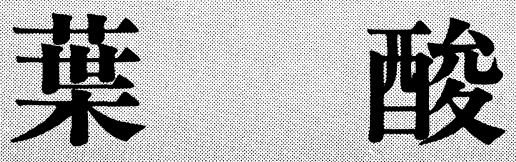

基礎と臨床

編集 京都大学内科教授 内野治人 岐阜歯科大学内科教授 外林秀紀 専門医18氏分担執筆

\section{A 5 判 484頁 図172 表104 定価9,800円(产200円)}

文部省科学総合研究「葉酸補酵素の臨床的応用に関する基礎的研究」の成果をふまえて, さらに最新の葉酸研究を包括して編集した。現時点までの文献をできるだけ集積し，ほぼ 完全な集大成ができた。葉酸に関するすべての知識はこの一冊に網羅されている。臨床医 のみならず，生化学，栄養学の基礎㧍よび応用に携わる方々の常備すべき一冊である。

一内容：第 1 章 緒言, 第 2 章 わが国における葉酸研究の歴史, 第 3 章 葉酸の基礎, I .概説, II.葉酸の定量法,

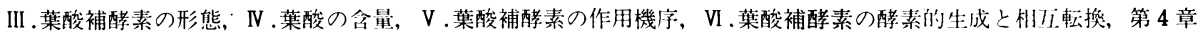
葉酸の臨床化学, I . 生体内運命, II.食品の葉酸測定と掑取量, III.食品中の葉酸のavailability, VV.放射性同位元

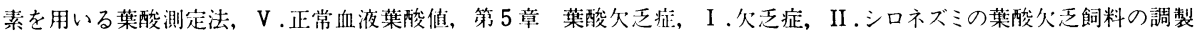
法とその応用, III. 無菌動物の葉酸代謝一葉酸代謝に対する晹内細菌の関与面一, IV.核酸代謝からみた葉酸欠泛精,

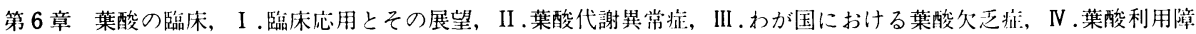
害, V.再生不良性贫血に扔ける葉酸㙩法に対する一考察，VI.再生不良性賓血に対する葉酸の効果。 